\title{
Development of an in vitro Dual Culture System for Grapevine and Xiphinema index as a Tool for Virus Transmission
}

\author{
P. Winterhagen ${ }^{1}$, G. Brendel ${ }^{2}$, G. $\operatorname{Krczal}^{1}$ and G. M. Reustle ${ }^{1 *}$ \\ (1) RLP AgroScience GmbH, AlPlanta - Institute for Plant Research, Breitenweg 71, 67435 Neustadt / Weinstraße, Germany \\ (2) Rebschule Steinmann e. K., Sandtal 1, 97286 Sommerhausen, Germany
}

Submitted for publication: September 2006

Accepted for publication: April 2007

Key words: Grapevine fanleaf virus; Xiphinema index; in vitro dual culture; virus inoculation

\begin{abstract}
Grapevine fanleaf virus (GFLV) is a nepovirus that is transmitted to grapevines by the ectoparasitic nematode Xiphinema index. GFLV causes severe losses in yield and quality in viticulture worldwide. Presently, laborious and time-consuming field trials or greenhouse tests are necessary for screening putative GFLV resistance in new grape genotypes developed in breeding programmes. We developed an in vitro dual culture system for grapevines and nematode vectors that requires less time and space than inoculation experiments done in the greenhouse. Virus infection of in vitro grapevines was investigated using immunocapture-reverse transcriptase-polymerase chain reaction (IC-RT-PCR) analysis. The development of root galls induced by feeding nematodes on in vitro grapevines was also analysed. Virus infection in grapevines in the dual culture with viruliferous nematodes was detected six weeks post-inoculation. Root galls were always absent from parasitised in vitro grapevines with detectable virus infection, whereas they developed on some parasitised, but virus-negative tested grapevines. Therefore, root galls cannot be used as a reliable indicator for parasitism and virus transmission.
\end{abstract}

\section{INTRODUCTION}

Grapevine fanleaf disease, caused by various nepoviruses, is responsible for severe losses in viticulture worldwide. The most economically important is grapevine fanleaf virus (GFLV), which is transmitted to grapevines by the soil-dwelling ectoparasitic vector nematode Xiphinema index (Longidoridae) (Andret-Link et al., 2004b; Hewitt et al., 1958). Natural resistance against grapevine fanleaf virus that could be used in breeding programmes has not been identified in any Vitis species. Consequently, several research groups focus their efforts on the introduction of virus resistance into rootstocks and scion varieties using a transgenic approach. This approach will require a simple and fast screening system for the evaluation of putative virusresistant grapevines. However, some Vitis species reveal tolerance of $X$. index. This could reduce the rate of inoculation, but grapevines remain susceptible to the virus (Andret-Link et al., 2004a).

Mechanical standard inoculation procedures are not applicable in grapevine, and biolistic virus delivery and infection via electroporation methods are difficult (Valat et al., 2003a; Valat et al., 2003b). Green grafting or micrografting are effective to infect grapevines (Lahogue and Boulard, 1996; Lahogue et al., 1995), but due to the high virus load that is delivered into the vascular system, this method seems to be inappropriate to evaluate virus resistance established at the cellular level, which is the place of virus replication (Lahogue and Boulard, 1996; Staudt, 1997; Valat et al., 2003a). Virus transmission using the vector nematode mirrors natural conditions and, therefore, this inoculation method will lead to the most reliable assessment of virus inoculation. However, testing candidate grapevines in field trials over several years is laborious, expensive and time consuming (Vigne et al., 2004; Walker and Wolpert, 1994). Furthermore, although nematode-mediated virus transmission under greenhouse conditions is possible, it is inconvenient for screening large numbers of candidate grapevines within a short time (Valat et al., 2003a).

The aim of the present work was to develop an in vitro dual culture system for virus transmission via Xiphinema index that will need few resources in terms of space and time. Parameters required to establish the in vitro dual culture were investigated, as well as their effect on nematode survival. Furthermore, the frequency of nematode-mediated virus infection and root gall development in in vitro grapevines was also investigated.

\section{MATERIAL AND METHODS}

\section{Establishment of a Xiphinema index population}

Xiphinema index was reared under greenhouse conditions on Ficus carica, which provided a permanent source of nematodes that could also be used as an aviruliferous control population. Viruliferous nematodes were obtained from exposure on GFLVinfected Vitis varieties (Herold, Portugieser, Müller-Thurgau and Sylvaner). The plants were grown in sand (grain size 0.2 to $0.5 \mathrm{~mm}$ ), which was heat sterilised at $200^{\circ} \mathrm{C}$ for $8 \mathrm{~h}$, and was placed in $3 \mathrm{~L}$ pots. The field capacity of the sand substrate was adjusted to approximately $60 \%$. Field capacity at $100 \%$ is the

\footnotetext{
*Corresponding author: e-mail address: goetz.reustle@agroscience.rlp.de.Fax: +49-6321-671-1313

Acknowledgements: The authors would like to thank U. Ipach and J. Hübschen for providing the initial Xiphinema index population for breeding and the primers for their molecular identification. We also thank A. Baßler and C. Kehrer for assistance in the tissue culture work. This work was supported by the BMWA (ProInno I-program). We are grateful to $L$. Kovacs and $M$. Odneal for critically reading the manuscript.
} 
amount of liquid held by the soil after excess water has drained due to gravitational force. The content of liquid was calculated by weighing and subtracting the dry weight of the substrate. Based on the weight of substrate and liquid, a percentage less than $100 \%$ of field capacity was calculated and adjusted.

\section{In vitro culture of grapevine}

In vitro grapevines were established from cuttings obtained from plants grown under greenhouse conditions. Young shoots were harvested, cleaned with ethanol $(70 \%)$, cut into one-node segments and surface sterilised with $\mathrm{CaOCl}(7 \%)$ for $20 \mathrm{~min}$. Cuttings were rinsed three times with sterile water and placed into culture tubes containing $1 / 2 \mathrm{MS}$ salts and vitamins (Murashige and Skoog, 1962), supplemented with 2.0\% sucrose and $0.3 \%$ gelan gum without growth regulators. Standard growth conditions for in vitro grapevines were $24^{\circ} \mathrm{C}$ and a $16 / 8 \mathrm{~h}$ light cycle $\left(60 \mu \mathrm{mol} \mathrm{m} \mathrm{m}^{-2} \mathrm{~s}^{-1}\right)$. These conditions enabled the growth of explants (5BB, 125AA, Binova, SO4) with a multiplication rate of five cuttings obtained from one plantlet within six weeks.

\section{In vitro dual culture of Xiphinema index and grapevine}

For the in vitro dual culture, sand (140 g, grain diameter 0.2 to $0.5 \mathrm{~mm}$ ) was used as substrate. The sand was placed in $1 / 2 \mathrm{~L}$ WECK jars, which were closed with a lid and a felt ring for better ventilation. The jars containing sand were autoclaved, dried and $1 / 2$ MS medium without gelan gum was added to the substrate to obtain a field capacity of $100 \%$. To adjust the field capacity to $100 \%, 37 \mathrm{~mL}$ of liquid was added to $140 \mathrm{~g}$ of sand. The medium with or without sucrose was adjusted to a $\mathrm{pH}$ of 5.8 or 7.0 respectively. Two grapevine cuttings were cultivated in each jar under standard growth conditions. Xiphinema index was added to the in vitro cultures after three weeks culture initiation, when the roots were approximately $2 \mathrm{~cm}$ long and the shoot length had reached 2 to $4 \mathrm{~cm}$. During the pre-incubation period, the field capacity of the sand substrate reached a value of about $60 \%$ due to evaporation. For dual culture initiation, nematodes of the greenhouse stocks were washed out, collected on a sieve with a mesh diameter of $40 \mu \mathrm{m}$, and adult individuals were handpicked using a bristle. Subsequently, nematodes were rinsed several times with sterile water to reduce the contamination of the dual culture during incubation. An additional disinfection treatment of the nematodes before inoculation, as described by Bavaresco and Walker (1994), was not carried out because of the reported negative effects on $X$. index survival and feeding behaviour. Desiccation of the nematodes on the substrate surface was prevented by placing the nematodes directly on the roots with the help of a sterile spatula. On the outside, the bottom of the jar was covered with tinfoil to avoid irritation of the nematodes by light influx. For the analysis, the plants were uprooted and the nematodes were washed out and collected for extraction.

\section{Virus detection in grapevine and nematodes}

Immunocapture (IC) reverse-transcriptase (RT)-PCR was used as a highly sensitive and reproducible system for virus detection in the grapevines, based on the description of Wetzel et al. (1992; 2002) and Valat et al. (2003b). For the IC step, samples of grapevine leaves and roots were homogenised separately in grapevine extraction buffer (Bioreba, Reinach, Switzerland) and chilled on ice. Microplates (Nunc) were coated (15 $\mathrm{mM} \mathrm{Na}_{2} \mathrm{CO}_{3}$, $33 \mathrm{mM} \mathrm{NaHCO}$, pH 9.6) with GFLV-specific antibody (1:1000,
Bioreba, Reinach, Switzerland), incubated at $37^{\circ} \mathrm{C}$ for $4 \mathrm{~h}$ and rinsed three times with washing buffer $(137 \mathrm{mM} \mathrm{NaCl}, 1.5 \mathrm{mM}$ $\mathrm{KH}_{2} \mathrm{PO}_{4}, 8 \mathrm{mM} \mathrm{Na} \mathrm{HPO}_{4}, 2.7 \mathrm{mM} \mathrm{KCl}, 5 \%$ Tween, $\mathrm{pH}$ 7.4). Samples $(150 \mu \mathrm{L})$ were loaded on coated microplates and incubated at $4{ }^{\circ} \mathrm{C}$ overnight. After rinsing the microplates three times with washing buffer, viral RNA was released from the virus particles by vortexing with $20 \mu \mathrm{L}$ TritonX100 $\left(10 \%, 70^{\circ} \mathrm{C}\right)$ for a few seconds.

Different protocols are described for RNA extraction from nematodes (Esmenjaud et al., 1994; Van der Wilk et al., 1994; Demangeat et al., 2004). However, for the extraction of total RNA from $X$. index we followed the protocol of Van der Wilk et al. (1994), which provides RNA applicable for RT-PCR assays within a short time. Nematodes were ground with glass beads by vortexing in $150 \mu \mathrm{L}$ DEPC-treated water for $5 \mathrm{~min}$. After extraction with chloroform, the RNA was precipitated with $2.7 \mathrm{vol}$ ethanol and 0.1 vol sodium acetate (3 M, pH 5.2) and dissolved in $10 \mu \mathrm{L}$ DEPCtreated water. Two $\mu \mathrm{L}$ of the obtained samples were analysed using the one-step RT-PCR kit Superscript II RT/Platinum Taq (Invitrogen, Karlsruhe, Germany), following the manufacturer's instructions. Species-specific primers $(10 \mathrm{mM})$ targeting the internal transcribed spacer (ITS) region of Xiphinema index were used for RT-PCR to check the quality of the extraction and to verify the species (Wang et al., 2003, Hübschen, unpublished). The thermal scheme for one-step RT-PCR was as follows: reverse transcription at $50^{\circ} \mathrm{C}(30 \mathrm{~min})$, initial denaturation at $94^{\circ} \mathrm{C}(5 \mathrm{~min}), 40$ cycles of denaturation at $94^{\circ} \mathrm{C}(1 \mathrm{~min})$, annealing at $57^{\circ} \mathrm{C}(45 \mathrm{sec})$, extension at $68^{\circ} \mathrm{C}(2 \mathrm{~min})$, and a final elongation step at $68^{\circ} \mathrm{C}(10 \mathrm{~min})$. The Xiphinema index-specific primers yield a PCR product of $340 \mathrm{bp}$.

The presence of virus in grapevines and nematodes was checked by GFLV-specific RT-PCR. Three $\mu \mathrm{L}$ of RNA samples were used for amplification with one-step RT-PCR, with the following thermal cycling scheme: reverse transcription at $50^{\circ} \mathrm{C}$ (30 min), initial denaturation at $95^{\circ} \mathrm{C}(5 \mathrm{~min}), 40$ cycles of denaturation at $95^{\circ} \mathrm{C}(30 \mathrm{sec})$, annealing at $55^{\circ} \mathrm{C}(30 \mathrm{sec})$, extension at $68^{\circ} \mathrm{C}(45 \mathrm{sec})$, and a final elongation step at $68^{\circ} \mathrm{C}(7 \mathrm{~min})$. The GFLV-specific primers (10 mM, for 5'-TAC CGA CTG GGA CGA ACA CAT TGG-3', rev 5'-AGA TTC ACG CCT TGG TTC CTC CTG-3') target a conserved region of the viral movement protein (MP) and yield an amplicon of $298 \mathrm{bp}$. PCR products were separated by electrophoresis in an ethidium bromide-containing agarose gel (1.0\%) and were visualised with UV-light illumination.

\section{RESULTS}

\section{Development of the dual culture system in vitro}

For the cultivation of Xiphinema index and grapevine plants in an in vitro dual culture system, the substrate for culturing $X$. index in the greenhouse and in vitro conditions for grapevines were combined. For each experiment, four to six one-node cuttings per rootstock (two per jar) were cultured. Experiments were repeated twice. The different rootstocks showed similar growth and, therefore, they were not further discriminated in the presented results. As no plant developed using LS medium (Linsmaier and Skoog, 1965 ) in initial experiments, only $1 / 2$ MS medium was used for the further studies. The results of the preliminary experiments with grapevines grown in vitro on sterilised sand as substrate under different conditions are summarised in Table 1. 
Root development and shoot growth were improved by adding $2 \%$ sucrose to the $1 / 2$ MS medium. Furthermore, a medium at $\mathrm{pH} 5.8$ yielded a more extended root system compared to a medium at $\mathrm{pH}$ 7.0. The roots of plants grown in the in vitro dual culture system showed root hairs, a pale brownish cortex, and were less fragile compared to roots grown in gelan gum-solidified medium in in vitro standard culture. The root system formed in the sand substrate appeared similar to the roots of grapevines grown in pots under greenhouse conditions.

A three-week period of pre-culture of the in vitro cuttings provided the plants with well-developed roots suitable for inoculation with $X$. index. The incubation time following the inoculation with 20 nematodes per jar was six weeks. Nematode survival rates of approximately $75 \%$ were found in sucrose-free jars, whereas nematodes were hardly able to survive in the dual cultures established with sucrose-containing medium (Table 1). There were only slight differences in the survival rate of nematodes between the medium at $\mathrm{pH} 5.8$ and at 7.0 respectively, but covering the outside of the jar bottom with tinfoil increased the survival rate (Table 1). In contrast to the results obtained by Sultan and Howard (1991), we found little effect of water content of the substrate in the initial experiments as long as the water content was within the range of 40 to $70 \%$ field capacity. To establish suitable conditions for plant development and the survival of the nematodes, jars with sucrose-free $1 / 2$ MS medium ( $\mathrm{pH} 5.8$ ) with tinfoil covering the jar bottoms were selected for further inoculation experiments.

\section{Inoculation experiments}

With reference to Staudt (1997), who suggested 20 plants per experiment for evaluation in greenhouse tests, we used this number of plants in our in vitro dual culture experiments. In each of the two experiments, 20 rootstock plantlets were inoculated with 20 nematodes per jar after three weeks pre-culture. After additional incubation of six weeks, a total of 37 of the plants could be analysed. The roots of 14 plants (38\%) tested positive for GFLV using IC-RT-PCR. Six of the plants with infected roots also revealed systemic infection of the shoot. Plants of all four test rootstocks were affected and no difference in susceptibility to virus infection or frequency of parasitism by the nematodes was found. The survival rate of the nematodes was $89 \%$ in these experiments. Nematodes were collected from each jar and pooled after the experiment, and total RNA was extracted. Before inoculation, the species and stage of development of individual $X$. index were verified by microscopy. The species was also confirmed through RT-PCR of total RNA extracts with $X$. indexspecific primers (Figure 1A). The RT-PCR assay with GFLVspecific primers revealed the presence of viral RNA in the extracts from the nematodes (Figure 1B).

Root galls were rarely found in the dual culture and did not appear before three weeks post-inoculation (Figure 2A). The in vitro galls were smaller and less conspicuous than the root galls from heavily-infested greenhouse cultures (Figure 2B), which revealed swollen tissue that often was accompanied by necrosis with small dark brown or even black spots.

Systemically, GFLV-infected grapevines were first found three weeks post-inoculation by investigation of leaf samples. However, the incubation period of the experiments lasted six weeks. Selected examples of inoculated grapevines analysed through IC-RT-PCR six weeks post-inoculation are presented in Figure 3. Roots and leaves of grapevine 1 (G1: R1, L1) indicate systemic infection, whereas in grapevine 2 (G2: R2, L1) virus infection was only detectable in the roots. Grapevine 3 (G3: R3, L3) is shown as an example of a parasitised but non-infected plant. It is important to note that the roots of the GFLV-positive grapevines G1 and G2 reveal no gall formation. Grapevine G3 showed root galls, although virus infection could not be detected in this plant. Overall, root galls were never visible after a sixweek incubation period on GFLV grapevines that had tested positive, but galls developed on the roots of three GFLV grapevines that had tested negative.

The presence of root galls in only those in vitro grapevines that had tested negative for GFLV after inoculation could be due to the feeding of aviruliferous nematodes. However, aviruliferous nematodes were rarely found in the stocks reared on GFLVinfected grapevines in the greenhouse. Aviruliferous individuals occur when attached virus particles are lost during the moult stage (Taylor and Robertson, 1970). Before becoming viruliferous again, the nematode needs to feed on a virus-infected plant. Alternatively, an explanation for the in vitro grapevines with root galls that tested negative for GFLV could be that the gall devel-

\section{TABLE 1}

The effect of various parameters influencing grapevine development and the survival of vector nematodes in in vitro dual culture.

\begin{tabular}{|c|c|c|c|c|c|}
\hline Tested plants (n) & Culture media $1 / 2$ MS $^{2}$ & $\begin{array}{c}\text { Cuttings with } \\
\text { roots }^{3}(\%)\end{array}$ & $\begin{array}{c}\text { Cuttings with } \\
\text { shoots }^{3}(\%)\end{array}$ & $\begin{array}{c}\text { Inoculated } \\
\text { X. } \text { index }^{4}(\mathrm{n})\end{array}$ & $\begin{array}{c}\text { Surviving } \\
\text { X. index } 5(\%)\end{array}$ \\
\hline 14 & $\mathrm{pH} 5.8 / 10 \mathrm{~g} / \mathrm{L}$ sucrose & 88 & 94 & 140 & 5 \\
\hline 16 & pH 5.8 & 75 & 81 & 160 & 51 \\
\hline 14 & $\mathrm{pH} 7.0 / 10 \mathrm{~g} / \mathrm{L}$ sucrose & 94 & 94 & 140 & 2 \\
\hline 14 & $\mathrm{pH} 7.0$ & 69 & 94 & 140 & 36 \\
\hline 12 & $\mathrm{pH} 5.8 / 10 \mathrm{~g} / \mathrm{L}$ sucrose $^{1}$ & 75 & 67 & 120 & 0 \\
\hline 16 & $\mathrm{pH} 5.8^{1}$ & 75 & 25 & 160 & 75 \\
\hline 12 & $\mathrm{pH} 7.0 / 10 \mathrm{~g} / \mathrm{L}$ sucrose $^{1}$ & 75 & 92 & 120 & 3 \\
\hline 12 & $\mathrm{pH} 7.0^{1}$ & 42 & 33 & 120 & 73 \\
\hline
\end{tabular}

Two plants per jar; ${ }^{1}$ bottom of jar was covered with tinfoil; ${ }^{2}$ field capacity for pre-culture was adjusted to $100 \%$;

${ }_{5}^{3}$ growth of plants estimated three weeks after pre-culture; ${ }^{4}$ inoculation with 20 individuals per jar;

5 estimated six weeks post-inoculation. 


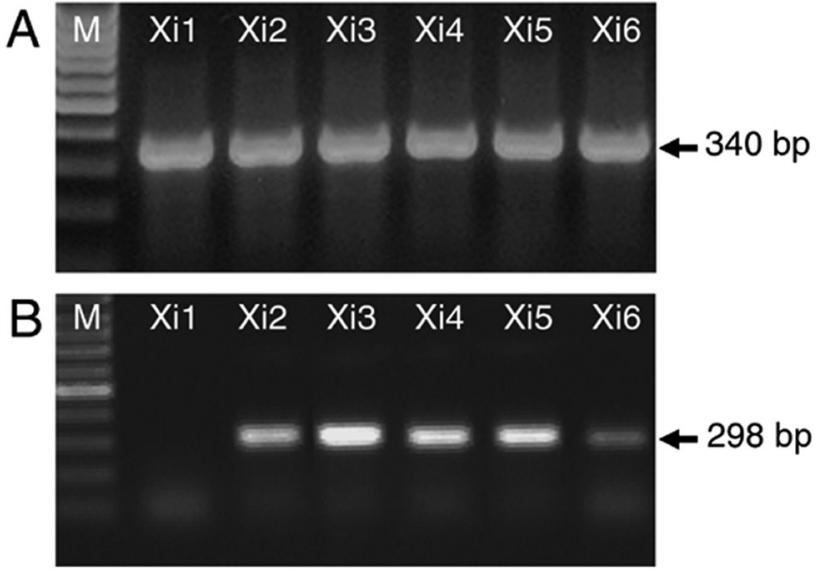

FIGURE 1

Identification of Xiphinema index and GFLV by RT-PCR of RNA extracts from pooled samples of 10 individuals each. (A) Detection of $X$. index, (B) detection of GFLV; Xi 1: X. index population from ficus (GFLV-free); Xi 2 to 6: different $X$. index populations reared on GFLV-infected grapevines; M: GeneRuler $100 \mathrm{bp}$ DNA-ladder, Fermentas.
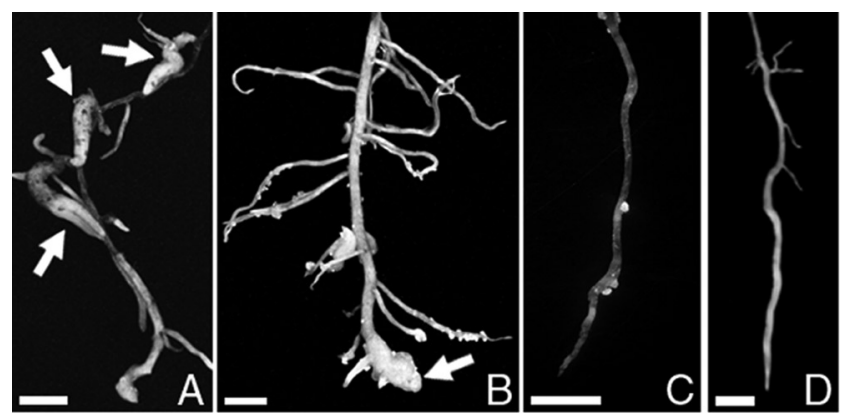

FIGURE 2

Grapevine roots with galls induced by parasitising Xiphinema index. (A) Root from in vitro sand culture showing gall development three weeks post inoculation (arrows). (B) Root from greenhouse culture with intensive gall formation, several months post inoculation (arrow). Healthy grapevine roots from in vitro (C) and greenhouse plants (D). Scale: $5 \mathrm{~mm}$.

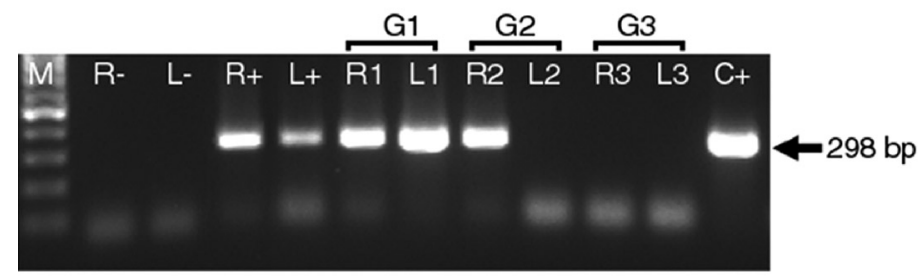

FIGURE 3

Virus detection by IC-RT-PCR. Non-infected roots (R-) and leaves (L-) as negative controls, and roots $(\mathrm{R}+)$ and leaves $(\mathrm{L}+)$ of a GFLV-infected grapevine as positive controls. Root and leaf samples (R1/L1 to R3/L3) from grapevine plants (G1 to G3) grown in the in vitro dual culture system for six weeks. Grapevine G3 developed root galls, but gall development was absent on the roots of grapevines G1 and G2. GFLV-specific amplification product of $298 \mathrm{bp}$. C+: cDNA of GFLV. M: GeneRuler 100 bp DNA ladder, Fermentas. opment of the parasitised roots might decrease the expansion and spreading of the virus due to compartmentalisation of the affected plant tissue. This could cause a delay or even inhibition of the infection in the roots of in vitro grapevines. However, the fact that the in vitro grapevine plants revealing virus infection after the inoculation did not develop root galls due to the parasitism of nematodes presently cannot be explained, because the trigger that is responsible for gall development is still unknown.

\section{DISCUSSION}

The establishment of an in vitro dual culture system for the inoculation of grapevine plants with GFLV using the natural transmission path has been described. The advantage of in vitro dual culture compared to infection experiments in greenhouses or in nematode-infested field trails is the shortening of the incubation time to approximately six weeks before detection of the established virus infection in the plant. In addition to the three weeks pre-culture, the entire inoculation experiment lasted only nine weeks. As reported by Staudt (1997), inoculation experiments on greenhouse grapevines last several months. Valat et al. (2003a) reported an overall nine-month period to complete virus transmission and infection under greenhouse conditions.

Due to the use of $1 / 2 \mathrm{~L}$ jars for the in vitro dual culture, the infection experiments need much less space than the experiments performed with containers in greenhouse experiments. Furthermore, the in vitro inoculation experiments were performed in a growth chamber under controlled environmental conditions, which are more stable than greenhouse conditions.

The small number of viruliferous nematodes per test (20 nematodes two in vitro plants) in the in vitro dual culture system allows higher numbers of infection experiments compared to greenhouse trials. Bouquet (1981) used 50 to 300 individuals per $\mathrm{kg}$ of soil, while Valat et al. (2003a) performed infection experiments in $25 \mathrm{~m}^{3}$ containers containing 100 to 150 viruliferous $X$. index per $\mathrm{kg}$ of soil. Similarly to greenhouse and field experiments, the infection rate of grapevines in the in vitro dual culture system may depend on the activity and the feeding behaviour of the nematodes. In our nematode stock population in the greenhouse, we found variability in propagation and feeding characteristics, but could not identify any influencing parameters.

Although the infection rate of about $38 \%$ seems to be low in the inoculation experiments with the in vitro dual culture, it should be noted that the incubation time was only six weeks. Lahogue et al. (1995) reported an infection rate of $51 \%$ after an incubation period of six months for virus inoculation by grafting. Considering this, the infection rate obtained with the in vitro dual culture appears absolutely competitive. Compared to micro- or green grafting of candidate genotypes onto infected grapevine rootstocks, this dual culture system simulates a natural infection process and theoretically enables a better evaluation and interpretation of resistance. Grafting methods can lead to a high load of virus particles in the candidate plant via the vascular system, making it difficult to efficiently inhibit the replication of the virus by a resistance mechanism at the cellular level. Lahogue and Boulard (1996) reported the limited reproducibility of the green grafting technique and concluded that green grafting was inappropriate for the identification of virus-resistant grapevine cultivars due to high inoculum pressure. Comparative experiments 
with different infection systems (e.g. green grafting, mechanical inoculation, bombardment) using transgenic, putative virus resistant (Jardak-Jamoussi et al., 2003; Reustle et al., 2003) and susceptible grapevines are in progress.

Furthermore, this study shows that the development of galls on the parasitised roots of in vitro grapevines is not a reliable indicator for nematode feeding and virus transmission. The development of root galls is obviously not always initiated by feeding nematodes on the roots of in vitro grapevines, because the in vitro grapevines that revealed GFLV infection after inoculation with nematodes did not develop root galls. It is recommended than an analysis with RT-PCR be performed to investigate if plants are infected with the virus after using the dual culture for inoculation.

\section{CONCLUSIONS}

The described reduction in space and time for virus inoculation with the in vitro dual culture system enables the testing and evaluation of large numbers of putative virus-resistant grapevines. New candidate plants developed and cultured in vitro can be tested directly without any adaptation to greenhouse conditions for inoculation experiments. Using the in vitro dual culture, only plants susceptible to GFLV should become infected after the feeding of viruliferous nematodes on the roots. Plant lines with a reliable resistance should theoretically not become infected with GFLV by nematodes. Candidate grapevines revealing GFLV infection after six weeks post-inoculation can be recognised and sorted out in an early stage of selection. Apart from this, uninfected plants of the same line with the identical genetic background should be evaluated with particular caution. These plants also might not have reliable virus resistance.

\section{LITERATURE CITED}

Andret-Link, P., Laporte, C., Valat, L., Ritzenthaler, C., Demangeat, G., Vigne, E., Laval, V., Pfeiffer, P., Stussi-Garaud, C. \& Fuchs, M., 2004a. Grapevine fanleaf virus: Still a major threat to the grapevine industry. J. Plant Pathol. 86(3), 183-195.

Andret-Link, P., Schmitt-Keichinger, C., Demangeat, G., Komar, V. \& Fuchs, M., 2004b. The specific transmission of grapevine fanleaf virus by its nematode vector Xiphinema index is solely determined by the viral coat protein. Virol. 320(1), 12-22.

Bavaresco, L. \& Walker, M.A., 1994. Techniques for successfully establishing Xiphinema index in dual culture with grape. Am. J. Enol. Vitic. 45(3), 273-277.

Bouquet, A., 1981. Resistance to grape fanleaf virus in Muscadine grape inoculated with Xiphinema index. Plant Dis., 65, 791-793.

Demangeat, G., Komar, V., Cornuet, P., Esmenjaud, D. \& Fuchs, M., 2004. Sensitive and reliable detection of grapevine fanleaf virus in a single Xiphinema index nematode vector. J. Virol. Meth. 122(1), 79-86.

Esmenjaud, D., Abad, P., Pinck, L. \& Walter, B., 1994. Detection of a region of the coat protein gene of grapevine fanleaf virus by RT-PCR in the nematode vector Xiphinema index. Plant Dis. 78(11), 1087-1090.
Hewitt, W.B., Raski, D.J. \& Goheen, A.C., 1958. Nematode vector of soil-borne fanleaf virus of grapevines. Phytopathol. 48, 586-595.

Jardak-Jamoussi, R., Bouamama, B., Wetzel, T., Mliki, A., Reustle, G.M. \& Ghorbel, A., 2003. Evaluation of different gene constructs for production of resistant grapevines against grapevine fanleaf and Arabis mosaic viruses. Acta Hort. $1(603), 315-324$

Lahogue, F. \& Boulard, G., 1996. Rechereche de gènes de résistance naturelle à deux viroses de la vigne: Le court-noué et l'enroulement. Vitis 35, 43-48.

Lahogue, F., Boulard, G. \& Schneider, C., 1995. Comparaison de différentes techniques de greffage vis-à-vis de leur efficacité de transmission virale sur vigne. Vitis $34,177-183$.

Linsmaier, E.M. \& Skoog, F., 1965. Organic growth factor requirements of tobacco tissue cultures. Physiol. Plant 18, 100-127.

Murashige, T. \& Skoog, F., 1962. A revised medium for rapid growth and bioassays with tobacco tissue culture. Physiol. Plant 15, 473-497.

Reustle, G.M., Wallbraun, M., Zwiebel, M., Wolf, R., Manthey, T., Burkhardt, C., Lerm, T., Vivier, M. \& Krczal, G., 2003. Selectable marker systems for genetic engineering of grapevine. Acta Hort. 2(603), 485-490.

Staudt, G., 1997. A quick-test for screening resistance to transmission of grapevine fanleaf virus by Xiphinema index. Vitis 36(3), 155-156.

Sultan, S.A. \& Howard, F., 1991. The effect of soil moisture and soil particle size on the survival and population increase of Xiphinema index. Rev. Nematol. 14(3), 345-351.

Taylor, C.E. \& Robertson, W.M., 1970. Sites of virus retention in the alimentary tract of the nematode vectors, Xiphinema diversicaudatum (Micol.) and X. index (Thorne and Allen). An. Appl. Biol. 66(3), 375-380.

Valat, L., Burrus, M., Fuchs, M. \& Mauro, M.-C., 2003a. Review of techniques to inoculate grapevines with grapevine fanleaf virus: Lessons and perspectives. Am. J. Enol. Vitic. 54(4), 279-285.

Valat, L., Mode, F., Mauro, M.C. \& Burrus, M., 2003b. Preliminary attempts to biolistic inoculation of grapevine fanleaf virus. J. Virol. Meth. 108(1), 29-40.

Van der Wilk, F., Korsman, M. \& Zoon, F., 1994. Detection of tobacco rattle virus in nematodes by reverse transcription and polymerase chain reaction. Eur. J. Plant Pathol. 100, 109-122.

Vigne, E., Komar, V. \& Fuchs, M., 2004. Field safety assessment of recombination in transgenic grapevines expressing the coat protein gene of grapevine fanleaf virus. Transgenic Res. 13(2), 165-79.

Walker, M.A. and Wolpert, J.A., 1994. Field screening of grapevine rootstock selections for resistance to fanleaf degeneration. Plant Dis. 78, 134-136.

Wang, X., Bosselut, N., Castagnogne, C., Voisin, R., Abad, P. \& Esmenjaud, D., 2003. Multiplex polymerase chain reaction identification of single individuals of longidorid nematodes Xiphinema index, $X$. diversicaudatum, X. vuittenzi, and $X$. italiae using specific primers from ribosomal genes. Phytopathol. 93, 160-166.

Wetzel, T., Candresse, T., Macquaire, G., Ravelonandro, M. \& Dunez, J., 1992. A highly sensitive immunocapture polymerase chain reaction method for plum pox potyvirus detection. J. Virol. Meth. 39, 27-37.

Wetzel, T., Jardak, R., Meunier, L., Ghorbel, A., Reustle, G.M. \& Krczal, G., 2002. Simultaneous RT/PCR detection and differentiation of arabis mosaic and grapevine fanleaf nepoviruses in grapevines with a single pair of primers. J. Virol. Meth. 101(1-2), 63-69. 